\title{
Moringa oleifera Extraction as Alternative Option for Controlling Citrus Post-harvest Green and Blue Molds In vetro
}

\author{
Basahi, R. A.
}

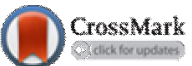

Department of Biology, Collage of Haq1, University of Tabuk, Saudi Arabia

Email: rbasahi@ut.edu.sa

Received on: $1 / 8 / 2019$

Accepted for publication on: 1/9/2019

\begin{abstract}
:
The post-harvest green and blue molds caused by Penicillium digitatum and Penicillium italicum, respectively are considered universal diseases that lead to the spoilage of almost all kinds of mature citrus fruits, and cause significant losses in citrus fruits during storage and in the markets greater than what people believes. Several natural products were used to control plant pathogens as alternative of fungicides. Moringa oleifera as a natural product was used to treat several plant pathogens. Penicillium digitatum and Penicillium italicum, were isolated from mature spoiled orange (Citrus sinensis L.) and lemon (Citrus limon L.) fruits obtained from the local market of Haqle - Saudi Arabia and identified using morphological and physiological characteristics according to the key of Visagie, in addition to molecular methods based on ITS1 sequence analysis. The fungicidal activity of Moringa oleifera extract with different concentrations in controlling the growth of the isolates of Penicillium digitatum and Penicillium italicum was determined in vitro. The control activity was highly dependent on Moringa oleifera extract concentration. For instance, undiluted Moringa oleifera extract showed the highest control activity with no growth as compared to the biotic control without treatment. Diluted Moringa oleifera extract $25 \%$ and $10 \%$ reduced the fungal growth to 46.54 and $29.88 \%$, respectively, for Penicillium digitatum and 45.83 and $27.46 \%$, respectively, for Penicillium italicum. The results of the recent study show that Moringa oleifera extract could successfully control Penicillium digitatum and Penicillium italicum, the disease agents of green and blue molds as an environmentally friendly product.
\end{abstract}

Keywords: Moringa oleifera, controlling citrus, post-harvest, green and blue molds in vetro

\section{Introduction:}

The post-harvest green and blue molds caused by Penicillium digitatum and Penicillium italicum, respectively are considered universal diseases that lead to the spoilage of almost all kinds of mature citrus fruits (Samson et al., 2004, Duan et al., 2016). Significant losses occurred by these pathogens on citrus fruits in the markets and storage. Farmers can not avid the damages of fruits when they transfer fruits from farms to markets (Smilanick et al., 2005, Kawai, et al., 2018). Moreover, farmers still using fungicides to save their products from green and blue molds and other molds fungi (Tripathi and Dubey, 2004, Duan et al., 2016). However, markets demands fruits without fungicides residues (Bhyan et al., 2007; Reddy et al., 2010).

There are different natural products used as alternative of fungi- 
cides to control plant pathogens (Nithyameenakshi et al., 2006; Saravanan et al., 2010; Hussein et al., 2011; Ashtiani et al., 2018; Chen et al., 2019). Alhussaen (et al., 2011) used successfully garlic extract in controlling Pythium ultimum in vitro isolated from tomato seedlings as environmentally friendly product. Other study was carried out by Rongai et al., 2017 using pomegranate peel aqueous extract (pae) to control the fusarium wilt of tomato caused by Fusarium oxysporum, f. sp. Lycopersici and reduced the population of Fusarium in soil resulting more healthy plants.

Moringa oleifera is the most widely used species of a monogeneric family, the Moringa oleifera ceae, that is native to the subHimalayan tracts of India, Pakistan, Bangladesh and Afghanistan. Moringa oleifera was used wildly as medicine in different countries all over the world, different parts of the plant used such as the stem bark, root, bark, fruit, flowers, leaves, seeds, and gum (Compaoré et al., 2011). Moringa oleifera was described in several studies and found their nutritional and medicinal properties (Anjorin, Ikokoh, \& Okolo, 2010). Anjorin et al., 2010 reported that Moringa oleifera leaves have vitamins and essential minerals such as vitamin $A$, vitamin $B$, vitamin $C$, calcium, iron, potassium, essential amino acids, and high protein content.

Moringa oleifera found to have an antifungal activities and was used to control several species of fungi (Nickon et al., 2003; Chuang et al., 2007; Moodley et al., 2018). Jabeen et al., 2008 pointed that Moringa oleifera extracts were used successfully on bacterial species Botugytis cinerea and fungi species Fusarium oxysporum and Mycfosphaerella arachidicola. Other studies examined the antimicrobial activity of the essential oil of Moringa oleifera against Pseudomonas aeruginosa, Bacillus cereus, Escherichia coli, Staphylococcus aureus and different fungal isolates Penicillium digitatum, Penicillium aurantiogriseum, Penicillium citrinum, Penicillium expansum and Aspergillus niger and found that all microorganisms tested were sensitive to the essential oil (Marrufo et al., 2013). Moreover, extracts of other parts of Moringa oleifera have been examined and control successfully bacterial growth of Streptococcus mutans and Staphylococcus aureus (Elgamily et al., 2016).

The present study was carried out to examine the effect of Moringa oleifera extract as an antifungal for green and blue molds caused by Penicillium digitatum and Penicillium italicum.

\section{Materials and Methods:}

Isolate recovery: Penicillium digitatum and Penicillium italicum, were isolated from mature spoiled orange (Citrus sinensis L.) and lemon (Citrus limon L.) fruits and identified using morphological and physiological characters. Fruits were obtained from the local market Haqle - Saudi Arabia. Complete media (CM) modified by Al-Najar (2007) was used to obtain optimal growth conditions for the tested fungal isolates. Isolates were grown for 7 to 10 days at $20-25^{\circ} \mathrm{C}$ on $\mathrm{CM}$ plates 
(Al-Najar, 2007) to confirm their purity and identity.

Molecular identification: DNA were extracted from the mycelium of the isolated Penicillium digitatum and Penicillium italicum according to Demirel et al., 2013 and the Internal Transcribed Spacer (IST1) region of the ribosomal nuclear DNA (rnDNA) was amplified using PCR. Standard methods were used to get the ITS1 sequencing and was carried out at a commercial facility (Macrogen Inc., Seoul, South Korea). BLAST search (http:// blast.ncbi.nlm.nih.gov) was used to analysis the sequences and ClustalW (http://www.ebi.ac.uk) used to find their relatives of the phylogram of the isolate.

\section{Moringa extraction and Penicillium treatment:}

The effect of Moringa oleifera extract against mycelial growth of Penicillium digitatum and Penicillium italicum was examined in September 2018. Moringa oleifera was extracted using the method mentioned by Chumarka et al., 2008.

Four concentrations $(10,25,50$ and $100 \%$ ) of Moringa oleifera extract were applied and sterilized distilled water was used as control. Three plates were used for each treatment. Inoculation was carried on by dispersing $1 \mathrm{~mL}$ of the Moringa oleifera extract from each treatment and added on the surface of each plate. Five millimeter disc was cut from the margin of an actively growing Penicillium digitatum and Penicillium italicum culture (5 days old) on CM media and incubated in the dark at $25 \pm 1^{\circ} \mathrm{C}$ as an inoculation. Plates with the different treatments were incubated at $25 \pm 1{ }^{\circ} \mathrm{C}$ on the dark. Growth of the mycelium was assessed daily as visual observation and the final assessment was recorded after 5 days of incubation using colony counter on Petri dish, by which the total area of the mycelial growth on each plate was measured.

Data analysis: All treatments were arranged in Completely Randomized Design (CRD) with 3 replicates for each treatment. The growth area was assessed using colony counter on Petri dish of each treatment. General Linear Model (GLM) ANOVA was used to find differences $(p \leq 0.05)$ between treatment means (SPSS VER 25).

\section{Results:}

\section{Sequence of ITS region of rDNA}

The sequences of Penicillium digitatum isolates obtained in this study was matched with Penicillium digitatum (DQ084021) from GenBank (Table 1). The sequence of isolate Penicillium digitatum was $668 \mathrm{bp}$ in length and was $100 \%$ identical to the corresponding sequence from Penicillium digitatum (DQ084021). Moreover, the sequences of Penicillium italicum isolates obtained in this study was matched with Penicillium italicum (AY291256) from Gen-Bank (Table 1). The sequence of isolate Penicillium italicum was $593 \mathrm{bp}$ in length and was $100 \%$ identical to the corresponding sequence from Penicillium italicum (AY291256). 
Table 1. Sequence length (bp) of ITS region of rDNA for 2 isolates of Penicillium digitatum and Penicillium italicum from fruits obtained from the local market of Haqle - Saudi Arabia and comparison with sequences in Gen-Bank.

\begin{tabular}{|c|l|c|c|c|}
\hline $\begin{array}{c}\text { Sequence } \\
\text { length } \\
\text { (bp) }\end{array}$ & Match from Gen-Bank (Location) & $\begin{array}{c}\text { Gen-Bank } \\
\text { accession } \\
\text { number }\end{array}$ & $\begin{array}{c}\text { Identities } \\
\mathbf{( \% )}\end{array}$ & Gaps \\
\hline 668 & Penicillium digitatum 2005 (USA) & DQ084021 & 100 & 0 \\
\hline 593 & Penicillium italicum 2003 (Sweden) & AY291256 & 100 & 0 \\
\hline
\end{tabular}

Effect of Moringa oleifera extract on the growth of Penicillium digitatum

Moringa oleifera extract was found to be effective to control Penicillium digitatum isolated from orange and lemon fruits obtained from the local market of Haqle - Saudi Arabia under in vitro conditions (Figure 1, Table 2). One hundred percent concentration of Moringa oleifera extract showed the highest growth inhibition activity. At this level, the fungus has no growth compared with the control (56.72 $\mathrm{cm}^{2}$ ) (Figure 1, Table 2). Moreover, $50 \%$ diluted Moringa oleifera extract reduced the fungal growth to $93.79 \%$ $\left(3.52 \mathrm{~cm}^{2}\right)$ compared with the control. The 25\% diluted Moringa oleifera extract reduced the fungal growth to $81.89 \%\left(10.52 \mathrm{~cm}^{2}\right)$ compared with the control. The last diluted Moringa oleifera extract $(10 \%)$ reduced the growth to $52.68 \%\left(26.84 \mathrm{~cm}^{2}\right)$ compared with the control.

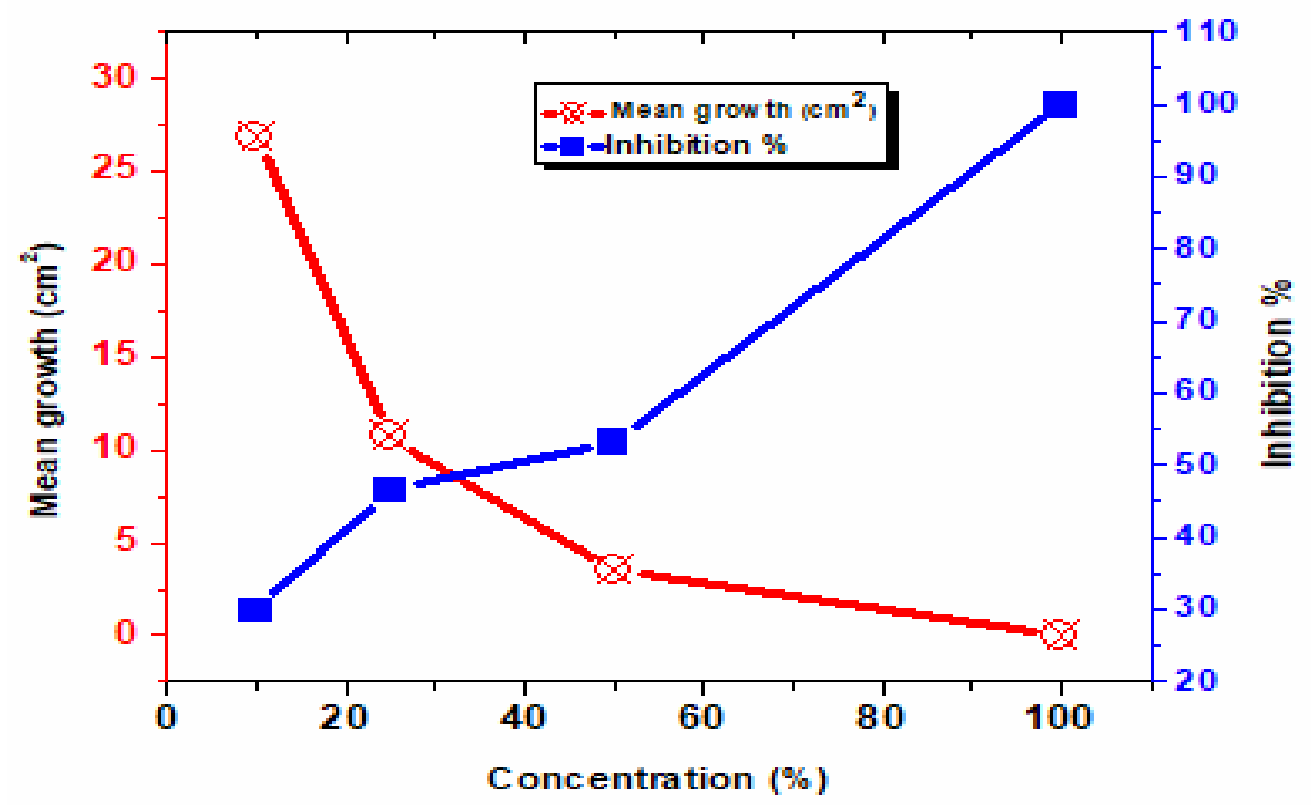

Figure 1: Mean growth area $\left(\mathrm{cm}^{2}\right)$ and the percentage of growth inhibition area of Penicillium digitatum due to treatment with different Moringa oleifera extract concentrations. 
Table 2. Mean growth area $\left(\mathrm{cm}^{2}\right)$ and the percentage of growth inhibition area of Penicillium digitatum due to treatment with different Moringa oleifera extract concentrations.

\begin{tabular}{lcc} 
Morin extract conc. & Mean growth $(\mathbf{c m} 2)$ & $\begin{array}{c}\text { Inhibition percentage } \\
(\mathbf{\%})\end{array}$ \\
\hline Full concentration $100 \%$ & $00.00^{\mathrm{a}}$ & 100.0 \\
\hline $50 \%$ & $03.52^{\mathrm{b}}$ & 93.79 \\
\hline $25 \%$ & $10.27^{\mathrm{c}}$ & 81.89 \\
\hline $10 \%$ & $26.84^{\mathrm{d}}$ & 52.68 \\
\hline Control & $56.72^{\mathrm{e}}$ & 0.00 \\
\hline
\end{tabular}

On the other hand, Penicillium italicum isolated from orange and lemon fruits obtained from the local market of Haqle - Saudi Arabia were controlled by Moringa oleifera extract under in vitro conditions (Table 3). One hundred percent concentration of Moringa oleifera extract showed the highest growth inhibition activity. At this level, the fungus has no growth compared with the control $\left(56.72 \mathrm{~cm}^{2}\right)$ (Figure 2, Table
3). The $50 \%$ concentration of the Moringa oleifera extract reduced the fungal growth to $92.82 \%\left(4.07 \mathrm{~cm}^{2}\right)$ compared with the control. The other diluted extract $25 \%$ reduced the fungal growth to $80.80 \%\left(10.89 \mathrm{~cm}^{2}\right)$ compared with the control. The final diluted Moringa oleifera extract $(10 \%)$ reduced the growth to $48.41 \%$ $\left(29.26 \mathrm{~cm}^{2}\right)$ compared with the control.

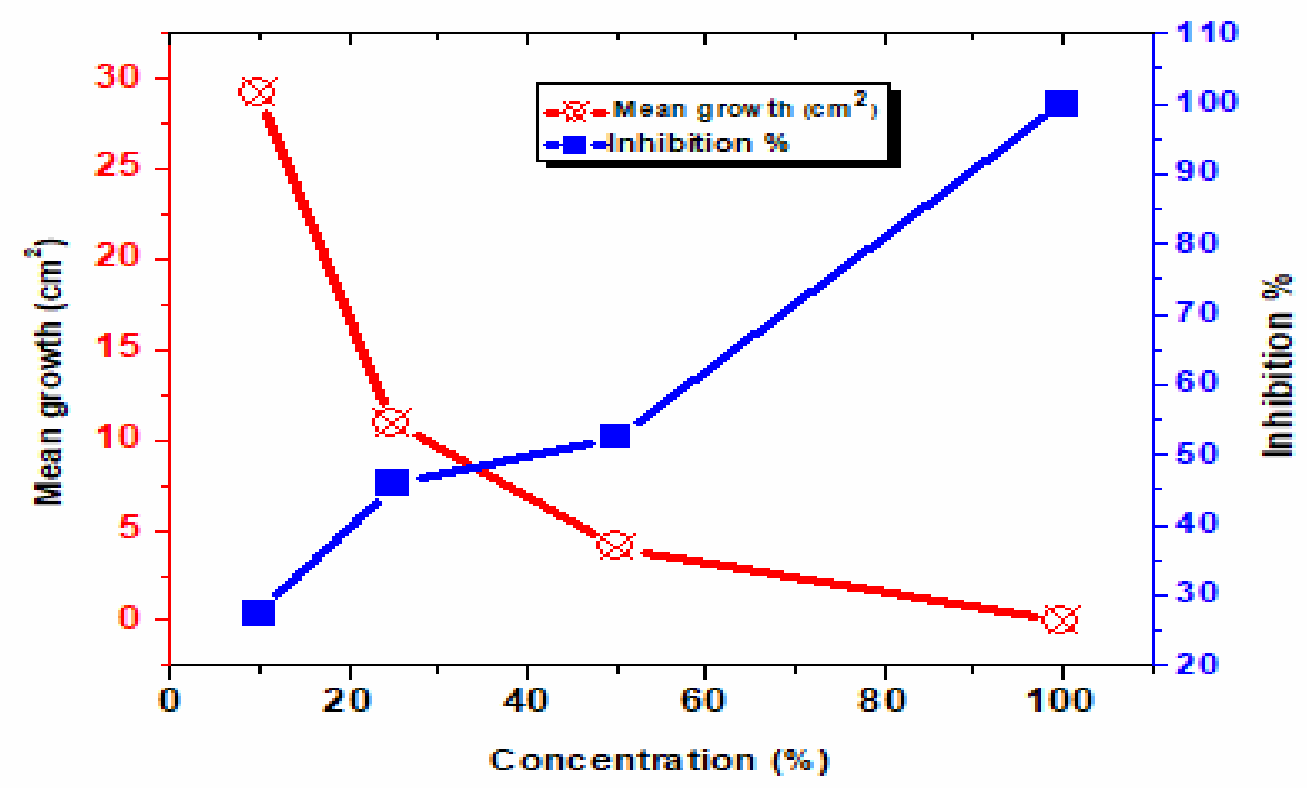

Figure 2: mean growth area $\left(\mathrm{cm}^{2}\right)$ and the percentage of growth inhibition area of Penicillium italicum due to treatment with different Moringa oleifera extract concentrations. 
Table 3. Mean growth area $\left(\mathrm{cm}^{2}\right)$ and the percentage of growth inhibition area of Penicillium italicum due to treatment with different Moringa oleifera extract concentrations

\begin{tabular}{|l|c|c|}
\hline Morin extract conc. & Mean growth (cm2) & Inhibition percentage (\%) \\
\hline Full concentration $100 \%$ & $00.00^{\mathrm{a}}$ & 100.0 \\
\hline $50 \%$ & $04.07^{\mathrm{b}}$ & 92.82 \\
\hline $25 \%$ & $10.89^{\mathrm{c}}$ & 80.80 \\
\hline $10 \%$ & $29.26^{\mathrm{d}}$ & 48.41 \\
\hline Control & $56.72^{\mathrm{e}}$ & 00.00 \\
\hline
\end{tabular}

\section{Discussion:}

Identification of plant pathogens is very important to find effective disease management methods. The incorrect identification could lead to ineffective control strategies and money losses. The traditional identification of fungi is using morphological characteristics but when some species have the same characteristics, the identification difficult will be (Agrios, 2005). In some fungi such as Pythium spp. features are similar among the groups as result of the environmental effect (Van Os, 2003).

Molecular methods have been used to identify plant pathogens and to understand the variation between the population by using several DNA methods (Levesque and de Cock, 2004; Drenth et al., 2006). The sequences of the Internal Transcibed Spacer (ITS1) region of the ribosomal DNA (rDNA) for Penicillium isolates were obtained for identification to species level. Penicillium digitatum isolate was found to be $100 \%$ identical to Penicillium digitatum (DQ084021) in the Gene-Bank database (Table 1). Moreover, isolate of Penicillium italicum was found to be $100 \%$ identical to Penicillium italicum (AY291256) in the Gen-Bank (Table 1). Identification by using sequences of its was confirm the identi- fication by using the morphological and physical characterization.

Moringa oleifera extract was found to be effective in this study when used to control Penicillium italicum and Penicillium digitatum in vitro and reduced the growth. Bukar et al., 2010 found that the Moringa oleifera leaf extract was effective in controlling bacteria species of Escherichia coli, Salmonella typhimurium and fungi of Mucor and Rhizopus. Moreover, other study found Moringa oleifera extract have an antifungal activity against the phytopathogenic fungi Fusarium solani, Fusarium oxysporum, Colletotrichum musae and Colletotrichum gloesporioides in vitro (Gifoni et al., 2012). Furthermore, Moringa oleifera extract was found to be effective against the plant pathogenic of Fusarium solani, Fusarium oxysporum, Alternaria solani, Alternaria alternaria, Rhizoctonia solani in vitro (Riad, et al., 2014).

In the present study, Moringa oleifera extract as low as $10 \%$ showed a good potential for reducing mycelial growth area to 26.84 $\mathrm{cm}^{2}$ of Penicillium digitatum and $29.26 \mathrm{~cm}^{2}$ of Penicillium italicum compared with the control (Table 1 and 2). These results demonstrate that Moringa oleifera extract even in low 
concentrations could be used to control green and blue molds caused by Penicillium digitatum and Penicillium italicum. Moreover, other Moringa oleifera extract concentrations used in the present study showed from slight reduction to complete inhibition of growth of the mycelia. These results agreed with the results of Maqsood et al., 2017 who study and explore In vitro antifungal activity of Moringa oleifera leaves against Aspergillus fumigatus, Aspergillus niger and Candida albicans at four different concentrations $\quad(50-300$ $\mathrm{mg} / \mathrm{ml}$ ) by ager well diffusion method. The maximum zone of inhibition was recorded in the case of methanolic leaves extract $(16 \mathrm{~mm})$ against Aspergillus niger at a concentration of $300 \mathrm{mg} / \mathrm{ml}$, which was at par to the standard antibiotic. Methanolic extract showed the highest MIC value $(70 \mathrm{mg} / \mathrm{ml})$ against Aspergillus niger.

\section{Conclusion:}

Moringa oleifera is a natural product was used to treat plant pathogens of Penicillium digitatum and Penicillium italicum isolated from mature spoiled orange and lemon fruits. Results of the present study highly recommended using Moringa oleifera extract in controlling Penicillium italicum and Penicillium digitatum.

\section{Acknowledgment:}

We are grateful thanks all persons introduced helping during this work

Conflict of interest: the author declare no conflict of interest

\section{References:}

Agrios GN 2005. 'Plant pathology.' (Academic Press: San Diego, USA)
Alhussaen Khalaf, Hussein Emad, AlBatayneh Khalid, Al-Khatib Mahmoud, Al Khateeb Wesam, Jacob Jacob, Shatnawi Mohamad, Khashroum Ashraf and Hegazy Mohamed, (2011). Identification and Controlling Pythium sp. Infecting Tomato Seedlings Cultivated in Jordan Valley using Garlic Extract. Asian Journal of Plant Pathology, 5: 84-92.

Al-Najar, R.A., 2007. Selection and evaluation of alternatives to synthetic fungicides for the control of post-harvest citrus fruits rot caused by Penicillium italicum (blue mould) in Jordan. M.Sc. Thesis, Mutah University, Jordan.

Anjorin, TS, Ikokoh P, Okolo S 2010. Mineral composition of Moringa oleifera leaves, pods and seeds from two regions in Abuja, Nigeria. International Journal of Agricultural Biology, 12:431-434.

Anjorin, T.S., P. Ikokoh and S. Okolo, 2010. Mineral composition of Moringa oleifera leaves, pods and seeds from two regions in Abuja, Nigeria. International Journal of Agricultural Biology, 12: 431-434.

Ashtiani A., Arzanlou M., Nasehi A., Kadir J., Vadamalai G. and Azadmard-Damirchi S. 2018. Plant tonic, a plant-derived bioactive natural product, exhibits antifungal activity against rice blast disease. 112, p: 105-112.

Bhyan, S.B., M.M. Alam and M.S. Ali, 2007. Effect of plant extracts on Okra mosaic virus incidence and yield related parameters of Okra. Asian Journal of Agriculture Research, 1: 112-118.

Bukar, A., A. Uba and Oyeyi, T. I. 2010. Antimicrobal profile of Moringa oleifera Lam. Extracts against Mal. Journal of Microbiology, 8(2): 5967. 
Chen, C., Qi, W., Peng, X., Chen, J., Wan, C. 2019. Inhibitory Effect of 7-Demethoxytylophorine on Penicillium italicum and its Possible Mechanism. Microorganisms, 7, 362.

Chuang, P., Lee C., Chou J., Murugan M., Shieh B. and Chen H. 2007. Anti-fungal activity of crude extracts and essential oil of Moringa oleifera Lam. Bioresource Technology. 98: 1. P: 232-236.

Chumarka, P., P. Khunawat, Y. Sanvarinda, S. Phornchirasilp, N. orales, L. Phivthong-ngam, P. Ratanachamnong, S. Srisawat, K. Pongrapeeporn, 2008. The in vitro and ex vivo antioxidant properties, hypolipidaemic and antiather.osclerotic activities of water extract of Moringa oleifera oleifera Lam. Leaves. Journal of Ethnopharmacology, 1-8.

Chumarka, P., P. Khunawat, Y. Sanvarinda, S. Phornchirasilp, N. orales, L. Phivthong-ngam, P. Ratanachamnong, S. Srisawat, K. Pongrapeeporn, 2008. The in vitro and ex vivo antioxidant properties, hypolipidaemic and antiather.osclerotic activities of water extract of Moringa oleifera Lam. Leaves. Journal of Ethnopharmacology, 1-8.

Compaore, W., Nikiena P., Bassole H., Savadogo A. and Mouecoucou J. 2011. Chemical Composition and Antioxidative Properties of Seeds of Moringa oleifera and Pulps of Parkia biglobosa and Adansonia digitata Commonly used in Food Fortification in Burkina Faso. Current Research Journal of Biological Sciences: 3. P: 64-72.

Demirel, R., Sariozlu N. and Ilhan S. 2013. Polymerase chain reaction (PCR) identification of terverticillate Penicillium species isolated from agricultural soils in eskişehir province. Brazilian Archives of Biology and Technology, 56 (6) pp. $980-984$.

Drenth, A., G. Wagels, B. Smith, B. Sendall, C. O'Dwyer, G. Irvine and J.A.G. Irwin, 2006. Development of a DNA-based method for detection and identification of Phytophthora species. Australian Plant Pathology, 35: 147-159.

Duan Xiaofang, Jing Guoxing, Fan Feng and Tao Nengguo 2016. Control of postharvest green and blue molds of citrus fruit by application of sodium dehydroacetate. Postharvest Biology and Technology, 113: 1719.

Duan Xiaofang, Jing Guoxing, Fan Feng and Tao Nengguo 2016. Control of postharvest green and blue molds of citrus fruit by application of sodium dehydroacetate. Postharvest Biology and Technology, 113: 1719.

Elgamily, H, Moussa A, Elboraey A, EL-Sayed H, Al-Moghazy M, Abdalla A. 2016. Microbiological Assessment of Moringa oleifera Extracts and Its Incorporation in Novel Dental Remedies against Some Oral Pathogens. Open Access Macedonian journal of Medical Sciences. 4(4): 585-590.

Gifoni, JM, Oliveira JTA, Oliveira HD, Batista AB, Pereira ML, Gomes AS, Oliveira, HP., Grangeiro, T. and Vasconcelos, M. 2012. A novel chitin-binding protein from Moringa oleifera oleifera seed with potential for plant disease control. Biopolymers. 98: 406-415.

Hussein Emad, Kanan Ghassan, AlBatayneh Khalid, Alhussaen Khalaf, Al Khateeb Wesam, Qar Janti, Jacob Jacob, Muhaidat Riyadh, and Hegazy Mohamed 2012. Evaluation of Food Preservatives, Low Toxicity Chemicals, Liquid 
Fractions of Plant Extracts and Their Combinations as Alternative Options for Controlling Citrus Post-Harvest Green and Blue Moulds 'In vitro'. Research Journal of Medicinal plant. 6, (8), pp. 551573.

Jabeen, R., Shahid, M., Jamil, A., \& Ashraf, M. 2008. Microscopic evaluation of the antimicrobial activity of seed extracts of Moringa oleifera. Pakistan Journal Botany, 40, 1349-1358.

Kawai, Y., Baba T., Yoshida M., Agravante J. and Carmen D. 2018. Effects of Benzyladenine and Light on Post-harvest Calamondin (x Citrofortunella microcarpa) Fruit Color and Quality. The Horticulture Journal Preview, 87: 3, p: 324328.

Levesque, C.A. and W.A. de Cock, 2004. Molecular phylogeny and taxonomy of the genus Pythium. Mycology Research, 108: 13631383.

Maqsood, M., Qureshi, R., Arshad, M., Ahmed, MS. and Ikram, M. 2017. Preliminary Phytochemical Screening, Antifungal and Cytotoxic Activities of Leaves Extract of Moringa oleifera Lam. from Satrange, Pakistan. Pakistan Journal of Botany, 49 (1): 353-359.

Marrufo, T., Nazzaro F., Mancini E., Fratianni F., Coppola R., Martino L., Agostinho A. and Feo V. 2013. Chemical Composition and Biological Activity of the Essential Oil from Leaves of Moringa oleifera Lam. Cultivated in Mozambique. Molecules 18(9), 10989-11000.

Moodley, J., Krishna S., Pillay K., Sershen and Govender P. 2018. Green synthesis of silver nanoparticles from Moringa oleifera leaf extracts and its antimicrobial potential. Advances in Natural Sciences:
Nanoscience and Nanotechnology. 9. 015008.

Nickon, F., Saud, Z.A., Rehman, M.H. and Haque, M.E. 2003. In vitro antimicrobial activity of the compound isolated from chloroform extract of Moringa oleifera Lam. Pakistan Journal of Biological Sciences, 22:1888 - 1890 .

Nithyameenakshi, S., Jeyaramraja P.R. and Manian S. 2006. Investigations on phytotoxicity of two new fungicides, azoxystrobin and difenoconazole. American Journal of Plant Physiology, 1: 89-98.

Reddy, K.R.N., S.B. Nurdijati and B. Salleh, 2010. An overview of plant-derived products on control of mycotoxigenic fungi and mycotoxins. Asian Journal Plant Sciences, 9: 126-133.

Riad, S.R. El-Mohamedy and Aboelfetoh M. Abdalla 2014. Evaluation of antifungal activity of Moringa oleifera extracts as natural fungicide against some plant pathogenic fungi In-vitro. Journal of Agricultural Technology 10 (4): 963-982.

Rongai D., Pulcini P., Pesce B. and Milano F. 2017. Antifungal activity of pomegranate peel extract against fusarium wilt of tomato. European Journal of Plant Pathology, 147, 1, p: 229-238.

Samson, R.A., K.A. Seifert, A.F.A. Kuijpers, J.A.M.P. Houbraken and J.C. Frisvad, 2004. Phylogenetic analysis of Penicillium subgenus Penicillium using partial $\beta$-tubulin sequences. Study of Mycology, 49: 175-200.

Saravanan, P., Ramya V., Sridhar H., Balamurugan $\mathrm{V}$. and Umamaheswari S. 2010. Antibacterial activity of Allium sativum L. on pathogenic bacterial strains. Global Veterinaria, 4: 519-522.

Smilanick, J.L., M.F. Mansour, D.A. Margosan, F. Mlikota-Gabler and 
W.R. Goodwine, 2005. Influence of $\mathrm{pH}$ and $\mathrm{NaHCO} 3$ on the effectiveness of imazalil to inhibit germination of spores of Penicillium digitatum and to control green mold on citrus fruit. Plant Disease, 89: 640-648.

Tripathi, P. and N.K. Dubey, 2004. Exploitation of natural products as an alternative strategy to control postharvest fungal rotting of fruit and vegetables. Postharvest Biology and Technology, 32: 235-245.

Van Os GJ 2003. Ecology and control of Pythium root rot in flower bulb culture. (Uitgeverij Eigen Beheer: Amesterdam).

Visagie, CM, Houbraken J, Frisvad JC, et al. 2014. Identification and nomenclature of the genus Penicillium. Studies in Mycology 78: 343-371. 
استخدام نبات المورنقا أوليفير ا كخيار بديل للسيطرة على أمر اض الأعفان الخضر اء والزرقاء

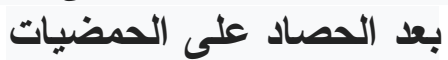

\section{رياض أبوبكر باصهي}

قسم الأحباء، الكلية الجامعية بحقل، جامعة تبوك، السعودية

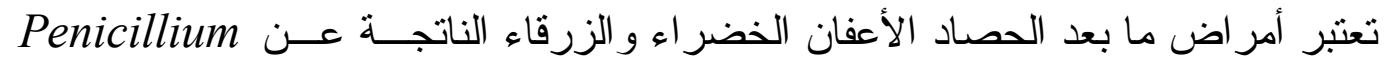

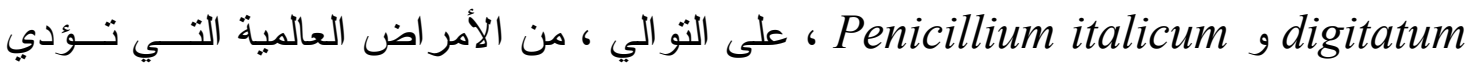

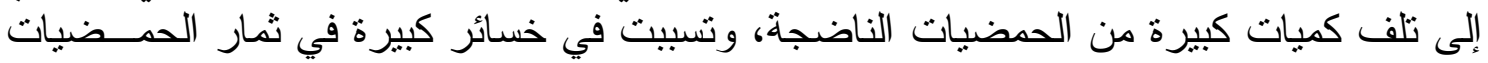

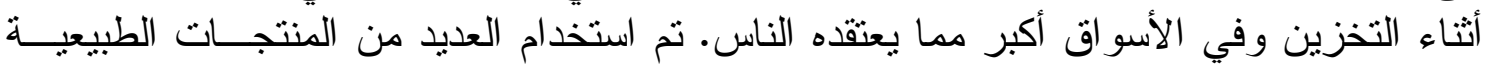

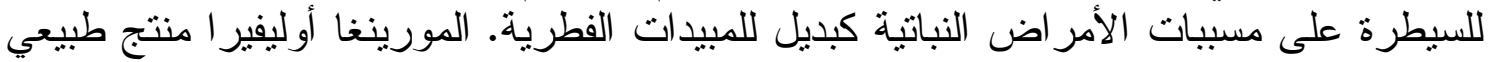

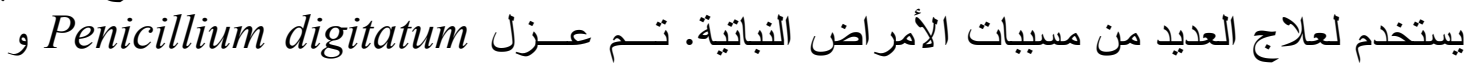

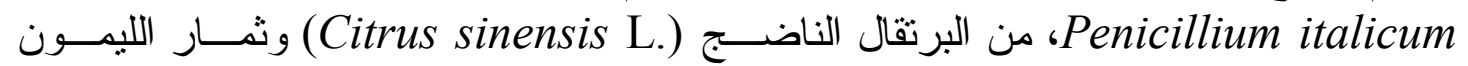
ونم الحصول عليها من السوق المحلية في محافظة حقل - منطقة تبوك- (Citrus limon L.)

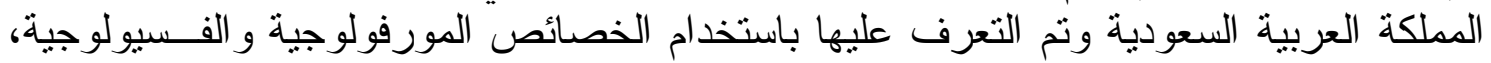

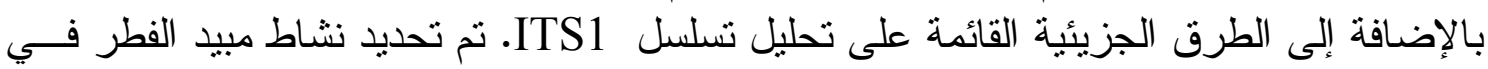

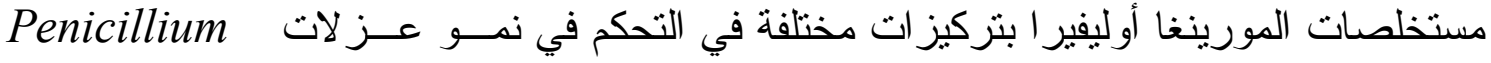

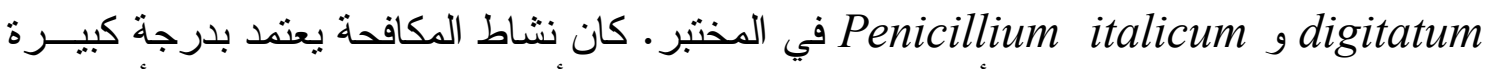

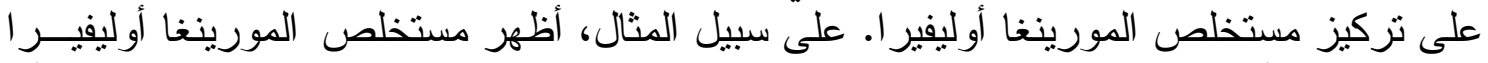

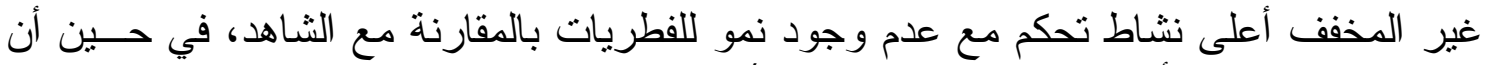

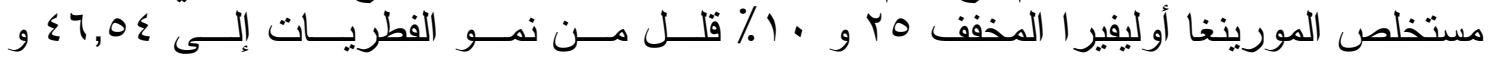

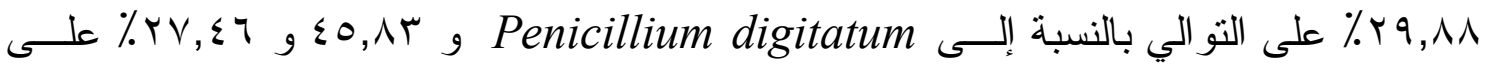

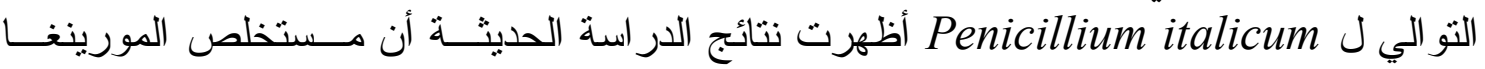

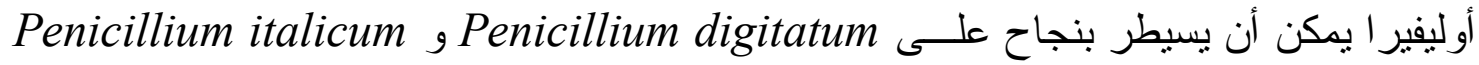
كعو امل مرضية للأعفان الخضر اء و الزرقاء كمنتج صديق للبيئة. 